Original Article

\title{
THE $N$-HEXANE FRACTION OF MYRMECODIA PENDANS INHIBITS CELL SURVIVAL AND PROLIFERATION IN COLON CANCER CELL LINE
}

\author{
MUHAMMAD HASAN BASHARI1,2*, SARAS HIDAYAT ${ }^{3}$, YASMIN ANISSA ROBLES RUSWANDI ${ }^{3}$, TENNY PUTRI ${ }^{4}$, \\ NURUL QOMARILLA ${ }^{4}$, RESTI GRADIA DWIWINA5, DIKDIK KURNIA6, MIEKE H. SATARI7 , FATHUL HUDA2,5
}

\begin{abstract}
1Departement of Pharmacology and Therapy, Faculty of Medicine, Universitas Padjadjaran, Bandung, Indonesia, ${ }^{2}$ Biomedical Science Master Program, Faculty of Medicine, Universitas Padjadjaran, Bandung, Indonesia, ${ }^{3}$ Undergraduate Program, Faculty of Medicine, Universitas Padjadjaran, Bandung, Indonesia ${ }^{4}$ Laboratory of Advanced Biomedicine, Universitas Padjadjaran, Bandung, Indonesia, 5Departement of Anatomy, Physiology, and Cellular Biology, Faculty of Medicine, Universitas Padjadjaran, Bandung, Indonesia, ${ }^{6}$ Departement of Chemistry, Faculty of Mathematics and Natural Sciences, Universitas Padjadjaran, Bandung, Indonesia, ${ }^{7}$ Departement of Oral Biology, Faculty of Dentistry, Universitas Padjadjaran, Bandung, Indonesia Email: bashari@unpad.ac.id
\end{abstract}

Received: 08 Aug 2017 Revised and Accepted: 22 Nov 2017

\section{ABSTRACT}

Objective: Despite advanced treatment options available for colorectal cancer, many reported resistance and unresponsiveness to conventional chemotherapeutic agents. Therefore, it is urgent to discover a novel drug for colon cancer. Sarang Semut (Myrmecodia pendans), an Indonesian native plant, has been studied extensively due to its anti-cancer profiles. This study aimed to evaluate the anti-tumour activity of Sarang Semut in colon cancer cells.

Methods: We evaluated cytotoxic activity of methanol extract as well as $n$-hexane and ethyl acetate fraction towards colon cancer cell lines (Caco-2 and HCT-116 cells) utilizing 3-[4,5-dimethylthiazol-2-yl]-2,5 diphenyl tetrazolium bromide (MTT) assay. The most potent fraction was evaluated further in inhibiting cell survival using MTT assay and cell proliferation using trypan blue exclusion assay as well as a clonogenic assay.

Results: Our data showed that the $n$-hexane fraction of Sarang Semut induces more cell death than the methanol extract and ethyl acetate fraction. Therefore, we analyzed the $n$-hexane fraction further and found that the inhibitory concentration $50 \%$ (IC $\mathrm{F}_{50}$ ) of the $n$-hexane fraction was 24 and 30 parts per million (ppm) for Caco-2 and HCT-116 cells, respectively. Moreover, it inhibited cell growth as well as cell colony formation, in particular, shown by the plating efficiency $(\mathrm{P}<0.05)$ and colony area per seed $(\mathrm{P}<0.01)$ of the control group were different to the treatment group.

Conclusion: The $n$-hexane fraction of Sarang Semut demonstrates a high potential antitumor activity in colon cancer cell line.

Keywords: Colorectal cancer, Myrmecodia pendans, Sarang Semut, cytotoxic assay, clonogenic assay

(C) 2018 The Authors. Published by Innovare Academic Sciences Pvt Ltd. This is an open access article under the CC BY license (http://creativecommons.org/licenses/by/4.0/) DOI: http://dx.doi.org/10.22159/ijpps.2018v10i1.21882

\section{INTRODUCTION}

Colorectal cancer is a major cause of morbidity and mortality in the world [1]. According to Global Burden of Cancer Study (GLOBOCAN) 2012, colorectal cancer is the third most common cancers in men (incidence of $746298,10.0 \%$ of the total cancer cases) and the second most common cancers in women (incidence of 614 304, $9.2 \%$ of the total cancer cases) worldwide and around half of them were death due to colorectal cancer [2].

Currently, patients with stage I or II colorectal cancer are treated with surgery, while patients with stage III colorectal cancer are treated with surgery followed by adjuvant chemotherapy, and patients with metastatic colorectal cancer (mCRC) are treated with systemic chemotherapies alone or in combination with targeted biologics [3-4]. However, most of the colon cancer patients develop resistance to adjuvant chemotherapy [5]. Despite advances in cytotoxic agents and targeted therapy available, resistance to chemotherapy remains one of the greatest challenges in long-term management of incurable metastatic disease and eventually contributes to death as tumors accumulate [5]. Therefore, it is urgent to discover a novel drug for colon cancer to overcome the resistance and provide better treatment response, which will lead to improving the survival of patients with colon cancer.

Sarang Semut (Myrmecodia pendans) is one of the traditional plants that have been used by locals in Indonesia to empirically treat various diseases [6-7]. Sarang Semut is a member of Rubiaceae family, which two genus are naturally become ant nest (Sarang Semut) including Myrmecodia (45 species) and Hypnophytum (26 species) [8]. Some studies have proven the efficacy of Sarang Semut in different cancer entities, including breast, uterus, tongue, and oral cancer [8-10]. Sarang Semut is typically found in Indonesia in particular in Papua and areas with tropical forests such as Sumatra, Borneo, and Toraja [11].

Chemical screening tests showed that Sarang Semut contains flavonoid and tannin [7-9]. Many mechanisms of action of flavonoid have been revealed, such as carcinogen inactivation, antiproliferation, apoptotic induction, antioxidants, inhibition of angiogenesis as well as cell cycle or combination of these mechanisms [12].

Here we aimed to evaluate anti-tumour activities of Sarang Semut in colon cancer cell lines (Caco-2 and HCT-116 cells).

\section{MATERIALS AND METHODS}

Chemicals and reagents

Dulbecco's modified eagle's medium (DMEM) fetal bovine serum (FBS), and penicillin-streptomycin were purchased from Gibco, USA. Dimethylsulfoxide (DMSO), 3-[4, 5-dimethylthiazol-2-yl]-2, 5 diphenyl tetrazolium bromide (MTT), and trypan blue were purchased from Sigma-Aldrich, USA. All the other chemicals of analytical grade were purchased from Merck, USA.

Cell culture and conditions

The Caco- 2 and HCT-116 cells are humans originated colorectal adenocarcinoma. Caco-2 was a gift from Prof. Henning SchulzeBergkamen (NCT, Heidelberg, Germany). HCT-116 was also a gift from Ahmad Faried, MD, PhD (Universitas Padjadjaran, Indonesia). 
Both cell lines were cultured using DMEM, supplemented with $10 \%$ FBS and $1 \%$ penicillin-streptomycin, incubated with a controlled temperature of $37^{\circ} \mathrm{C}$ and $5 \% \mathrm{CO}_{2}$ [13].

\section{Preparation of extracts and fraction of sarang semut}

Dried Sarang Semut was collected in June 2014 from Papua, Indonesia. The specimen was determined and deposited at Laboratory of Plants Taxonomy, Department of Biology, Faculty of Mathematics and Natural Sciences, Universitas Padjadjaran, Indonesia. Briefly, the Sarang Semut hypocotyl/tuber is sorted, washed with water, cleaned, cut, sliced into small pieces, dried and grounded into dry powder. This grounded Sarang Semut was then macerated with methanol for 2-3 d followed by filtration then evaporated and dried into a dry powder. This methanol extract was then partitioned using $n$-hexane or ethyl acetate to produce $n$ hexane fraction or ethyl acetate fraction.

A stock solution of $40000 \mathrm{ppm}$ was made in DMSO. The stock solution was further diluted to obtain the appropriate concentration.

\section{Cytotoxicity assay}

The cytotoxic effect of extract or fraction of Sarang Semut was evaluated in colon cancer cells using MTT assay, modified from our previous study [14-15]. Briefly, cells were seeded on 96-well plate then treated with indicated concentrations on the next day followed by incubation for $72 \mathrm{~h}$ in an incubator with $5 \% \mathrm{CO}_{2}$ at the temperature of $37{ }^{\circ} \mathrm{C}$. Cells with $1 \%$ DMSO were used as a control. The MTT solution was added and incubated for $4 \mathrm{~h}$ before DMSO was added to dissolve the formazan crystal. Absorbance was measured at the wavelength of $450 \mathrm{~nm}$ for finding the percentages of viable cells on treated cells compared to the control cells.

\section{Trypan blue exclusion assay}

Cells were seeded on a 6-well plate and incubated for $24 \mathrm{~h}$ before treated with indicated concentrations of $n$-hexane fraction of Sarang Semut. Cells were harvested, stained with trypan blue and counted under a microscope at $0,24,48$, and $72 \mathrm{~h}$ after treatment [16]. We also calculated the doubling time of $n$-hexane fraction of Sarang Semut to determine its anti-proliferative effect. The formula for calculating doubling time:

\section{Doubling time $=\mathrm{T} \ln 2 / \ln (\mathrm{Xe} / \mathrm{Xb})$}

Where $\mathrm{T}$ is incubation time, $\mathrm{Xe}$ is the number of cells after incubation, and $\mathrm{Xb}$ is the number of cells seeded.

\section{Clonogenic assay}

To evaluate the anti-proliferative effect of Sarang Semut, we used clonogenic assay or colony formation assay by analyzing plating efficiency (PE) and area per seed according to the previous study [17]. Briefly, an indicated numbers of the colon cancer cells number were seeded on 6-well plate, respectively. After the cells were attached to the well, they were untreated (control) or treated with $n$-hexane fraction of Sarang Semut for $3 \mathrm{~d}$ then the medium was replaced with a fresh complete medium and incubated for $2 \mathrm{w}$. Control group was treated with complete medium containing $1 \%$ DMSO. On the last day, the medium was removed, cells were fixed with methanol for 5 min followed by staining with crystal violet for 3 min then rinsed with tap water [17].

The number of colonies formed was counted manually by measuring each of colonies using a ruler. The colony was counted if the diameter measured more than $1 \mathrm{~mm}$. The formula for calculating PE:

$$
\mathrm{PE}(\%)=\frac{\text { number of colony formed }}{\text { number of cells seeded }} \times 100 \%
$$

The area of the colony was calculated semi-automatically by scanning the plate, then measuring the area using Colony Area plugin in ImageJ software (NIH, USA) [18]. The formula for calculating area per cell seeded:

$$
\text { Area per seed }(\mathrm{mm} 2)=\frac{\text { total area of colony formed }}{\text { number of cells seeded }}
$$

\section{Statistical analysis}

Drug curves, as well as $\mathrm{IC}_{50}$ were created and predicted using four parametric logistic regression by Sigmaplot ver.12 (SYSTAT Software Inc., USA). Data from clonogenic assay results in PE (\%) and area per seed $\left(\mathrm{mm}^{2}\right)$ that were analyzed using the statistical product and service solutions version 20 (SPSS; IBM, USA). To determine the association of inhibition of colony formation by each treatment group, we used one-way analysis of variance (ANOVA) test with post-hoc least significance difference (LSD) for plating efficiency and Tukey for area per seed. The statistical analysis was considered significant if $\mathrm{P}$ value $<0.05$.

\section{RESULTS}

The $n$-hexane fraction of sarang semut has potent cytotoxic activity in Caco-2 and HCT-116 cells

We started with an evaluation of cytotoxic activity of different extract or fraction of Sarang Semut in Coco- 2 cells. Our data showed that the $n$-hexane fraction induced more cell death of Caco- 2 cells compared to the methanol extract as well as ethyl acetate fraction (fig. 1). Percentage of cell death was 56.27, 88.43 and 70.38 upon treatment of $50 \mathrm{ppm}$ of methanol extract, $n$-hexane fraction and ethyl acetate fraction, respectively. Moreover, both concentrations of 50 , as well as $100 \mathrm{ppm}$ of $n$-hexane fraction, triggered cell death more than $80 \%$ indicating that $n$-hexane fraction is promising to be evaluated further.

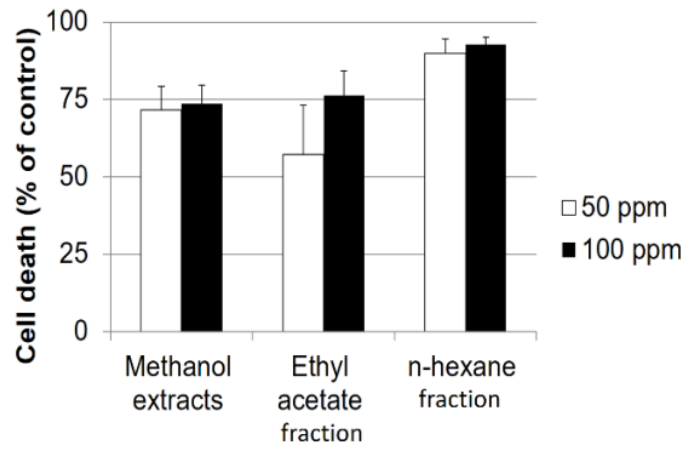

Fig. 1: The $n$-hexane fraction of sarang semut triggers cell death in Caco-2 cells. Caco-2 cells were untreated or treated with indicated concentration of extract or fractions of sarang semut for $\mathbf{3} \mathbf{d}$ followed by cytotoxic analysis using MTT assay. Data was presented as mean, SD, of triplication of three individual experiments

We then conducted a further cytotoxic assay of $n$-hexane fraction of Sarang Semut in colon cancer cells, HCT-116 and Caco-2. Interestingly, $n$-hexane fraction actively induced cell death in both cell lines in a dose-dependent manner (fig. 2). The IC ${ }_{50}$ of $n$-hexane fraction was achieved at 33 and 24 ppm in HCT-116 and Caco-2, respectively.

HCT-116 cells are known to have KRAS mutation while Caco- 2 cells are wild type [19-20]. KRAS mutations in colon cancer contribute to aggressive cancer phenotype and poorer prognostic [21].

The $n$-hexane fraction of sarang semut inhibits cell growth in Caco- 2 cells

Next, we evaluated cell growth using trypan blue exclusion assay. Consistently, out data showed that concentration of $15 \mathrm{ppm}$ of $n$ hexane fraction of Sarang Semut inhibited cell growth (fig. 3a). Increasing of viable cells numbers were depleted upon treatment of $n$-hexane fraction. Moreover, the doubling time of control cells and treated cells at $48 \mathrm{~h}$ after treatment were 11 and $25 \mathrm{~h}$, respectively. In addition, the portion of non-viable cells was bigger in the exposure of $n$-hexane fraction (fig. $3 \mathrm{~b}$ ). At $48 \mathrm{~h}$ after treatment, the percentage of non-viable cells to total cells were 15.2 and 49.2 in control and $n$-hexane fraction, respectively. 

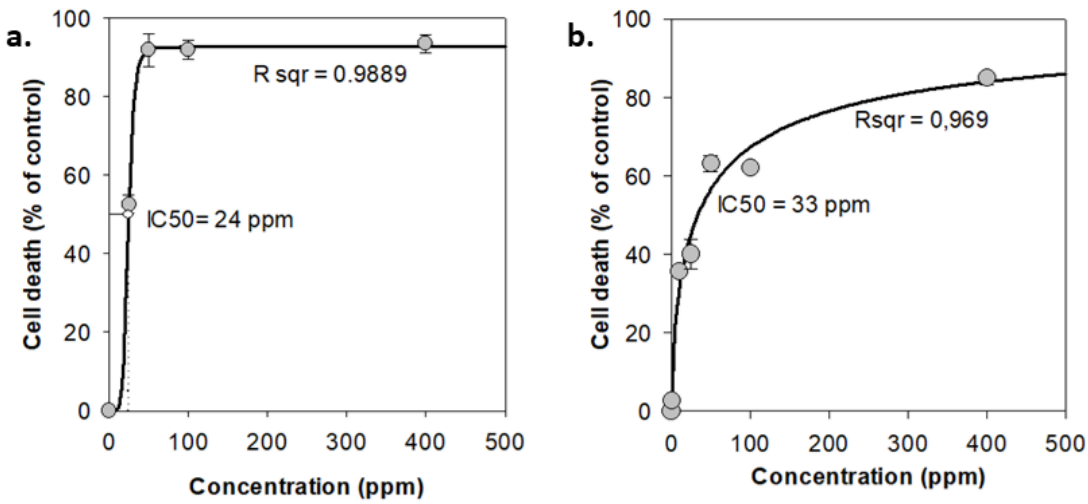

Fig. 2: The $n$-hexane fraction of sarang semut inhibits cell survival of colon cancer cells, Caco-2 (a) and HCT-116 (b) cells were untreated or treated with indicated concentration of $n$-hexane fraction of sarang semut for $3 \mathbf{d}$ followed by cytotoxic analysis using MTT assay. Data was presented as mean, SD, of triplication from three individual experiments. Drug curves, as well as IC $\mathrm{IC}_{50}$, were created and predicted using four parametric logistic regression by Sigmaplot ver.12

a.

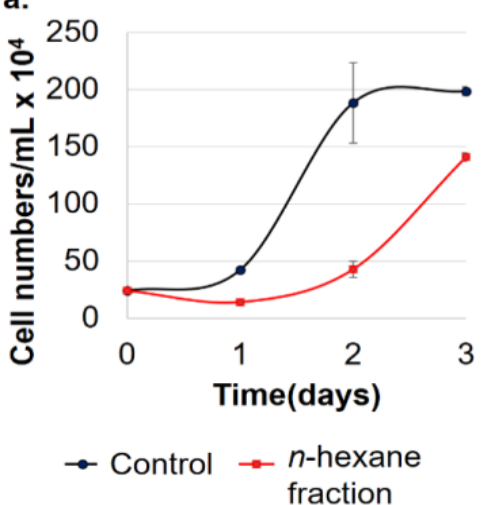

b.

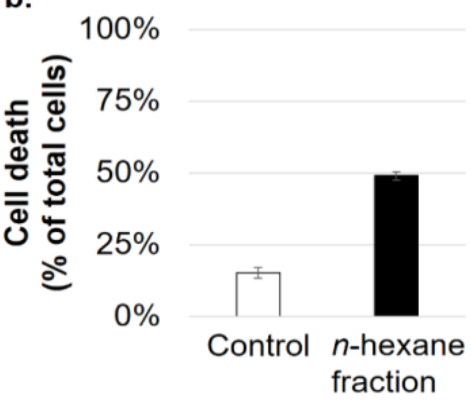

Fig. 3: The $n$-hexane fraction of sarang semut inhibits growth and survival of Caco- 2 cells, the $n$-hexane fraction suppressed cell numbers (a) and induced cell death (b) of Caco- 2 cells. Caco- 2 cells were untreated or treated with 15 ppm of $n$-hexane fractions. Cell numbers were counted at $0,24,48$ and $72 \mathrm{~h}$ after treatment using trypan blue exclusion assay, data were presented as mean, SD of triplication of three individual experiments

The $n$-hexane fraction of sarang semut inhibits colony formation in Caco-2 cells

Data above indicate that $n$-hexane fraction of Sarang Semut not only induces cell death but also inhibits cell proliferation. To further confirm these findings, we utilized clonogenic assay or colony formation assay. The colony formation of Caco-2 cells after $3 \mathrm{~d}$ of treatment and $2 \mathrm{w}$ of incubation were shown (fig. $4 a)$.

Our data showed that the PE decreases upon treatment of $n$-hexane fraction in a dose-dependent manner (fig. 4b). PE of control group, 2 and $15 \mathrm{ppm}$ group are $52.00 \% \pm 0.191,34.25 \% \pm 0.061$ and $24.37 \% \pm 0.083$, respectively.

We then analyzed area of the colonies formed. We can see in fig. $4 \mathrm{a}$ that area was clearly increased in $15 \mathrm{ppm}$ group compared to $2 \mathrm{ppm}$ group.

But, after divided by the number of cells seeded, the area per seed was also significantly decreased in a dose-dependent manner (fig. 4c). The area per seed of control group, 2 and $15 \mathrm{ppm}$ group are $2.295 \mathrm{~mm}^{2} \pm 0.083,1.143 \mathrm{~mm}^{2} \pm 0.383$, and $0.778 \mathrm{~mm}^{2} \pm 0.338$, respectively.

ANOVA test showed that $n$-hexane fraction of Sarang Semut has a significant effect of colony formation inhibition, as shown by PE (P = $0.01)$ and area per seed $(P=0.003)$ between treatment and control group.

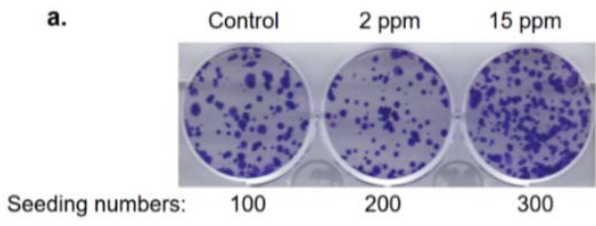

b.
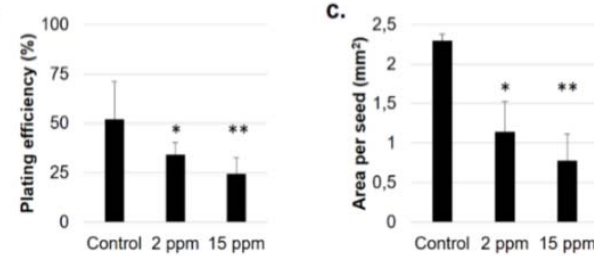

Fig. 4: The $n$-hexane fraction of Sarang semut inhibits colony formation in Caco-2 cells, a colony of Caco- 2 cells after fixation and staining (a). The $n$-hexane fraction of Sarang semut inhibits colony formation in Caco-2 cells plating efficiency (b) and area per seed (c). Caco-2 cells were seeded on 6-well plate and treated with $n$-hexane fraction of Sarang semut or untreated as

indicated for $3 \mathbf{d}$ followed by replacing with new culture medium then incubated for $2 \mathrm{w}$. Colonies were fixed and stained with crystal violet. Colony numbers were counted manually. Area per seed was calculated using ImageJ software. Data were presented as mean \pm SD from duplicate of 3 individual experiments $\left({ }^{*} \mathrm{P}<0.05,{ }^{* *} \mathrm{P}<0.01\right.$ to control) 
Post-hoc analysis for PE showed there was a significant difference between the control group and the $2 \mathrm{ppm}$ group $(\mathrm{P}=0.033)$, and between the control group and the $15 \mathrm{ppm}$ group $(\mathrm{P}=0.003)$. However, there was no statistically significant difference between the $2 \mathrm{ppm}$ group and the $15 \mathrm{ppm}$ group $(\mathrm{P}=0.182)$.

For the area per seed, post-hoc analysis showed there was a significant difference between the control group and the $2 \mathrm{ppm}$ group $(\mathrm{P}=0.015)$, and between the control group and the 15 ppm group $(P=0.002)$. However, there was no statistically significant difference between the $2 \mathrm{ppm}$ group and the $15 \mathrm{ppm}$ group $(\mathrm{P}=0.494)$.

\section{DISCUSSION}

Carcinogenesis is a complex process of cancer formation in which molecular and cellular alterations occur from the normal cells. There are three stages of carcinogenesis; initiation, promotion, and progression. Initiation is a rapid phase, consisting of exposure and interaction of cells, particularly DNA, with carcinogenic agents. Promotion is the second phase, in which the abnormal cells persist, replicate, and form pre-neoplastic cells. The final stage is progression, involving the gradual shift of premalignant cells to neoplastic cells with increased invasiveness, metastasis and the formation of new blood vessels (angiogenesis) [12].

Sarang Semut is an Indonesian plant that can be found in Papua, and areas with tropical forests such as Sumatra, Borneo, and Toraja [11] It is traditionally used for the treatment of various diseases, from minor ailments such as nausea to severe illnesses such as breast cancer [6].

Previous studies revealed that flavonoids are the main active compounds in Sarang Semut. Flavonoids can be obtained from different extractions, including $n$-hexane fractionation. A phytochemical study of Sarang Semut reported active phenolic compounds found in ethanol $70 \%$ extract and boiling water extract including flavonoids, tannin, phenolic, and alkaloid [7]. Other study showed that water extract of Sarang Semut contains flavonoid compounds, saponin, glycoside, and tannin; while the $n$-butanol extract contains flavonoids, tannins, and quinons; and the ethyl acetate extract contains only flavonoids and tannins [8]. Flavonoid compounds were also found in ethyl acetate, methanol, as well as ethanol extract and also in ethyl acetate fraction as well as $n$-hexane fraction of Sarang Semut [22, 23].

Flavonoids are polyphenol compounds derived from 2-phenylchromane commonly found in many plants, vegetables and flowers [24]. Flavonoids have several benefits for human health, such as antioxidant activity, anti-proliferative, anti-cancer, anti-bacterial, anti-inflammatory, anti-allergic and anti-viral effects [24].

Many researchers have conducted in vitro studies on anticancer activity potential of flavonoids in various cell lines including in breast cancer, oral cancer, thyroid cancer, lung cancer, prostate cancer, leukemia as well as colon cancer cell lines [12].

The molecular mechanism of flavonoids in cancer prevention remains unclear; some studies proposed that flavonoids interact with different types of genes and enzymes. Some mechanisms of action of flavonoids have been identified, such as inactivation of carcinogens, anti-proliferation, cell cycle inhibition, apoptotic induction, inhibition of angiogenesis, antioxidants, or the combination of such mechanisms [12].

Recent studies showed the potency of Sarang Semut in different cancer entities. Until now, studies tested Sarang Semut were in extract or fraction levels. It demonstrates different finding of IC $\mathrm{C}_{50}$ in different cancer cell lines (table 1).

Table 1: Cytotoxic activity of sarang semut

\begin{tabular}{llll}
\hline Cancer cell lines & Extraction methods & IC & References \\
\hline KB (oral cancer) & Ethanol extract & 215 \\
B88 (tongue cancer) & Ethanol extract & {$[10]$} & 471.79 \\
SCOV-3 (ovarian cancer) & Terpenoid bioactive compound & 463 \\
SP-C1 (tongue cancer) & Ethyl acetate fraction & 452.06 \\
SP-C1 (tongue cancer) & Ethanol extract & 938 \\
SP-C1 (tongue cancer) & Hexane fraction & {$[26]$} & 2691 \\
SP-C1 (tongue cancer) & Water extract & 12302.69 \\
Hela cell (cervical cancer) & Water extract & {$[9]$} \\
MCM-B2 cell (canine mammary tumor cell) & Water extract & {$[9]$} & 27.61 \\
\hline
\end{tabular}

Here, we analyzed the anti-tumour activities of $n$-hexane extract of Sarang Semut in colon cancer. A functional assay that was tested in this study were cytotoxicity and antiproliferative effect of Sarang Semut. Our data revealed better results than previous studies that the $\mathrm{IC}_{50}$ of the $n$-hexane fraction of Sarang Semut in colon cancer cells, Caco- 2 and HCT-116, are 24 and 33 ppm, respectively. This data indicates that $n$-hexane fraction inhibits cell survival and has potent cytotoxic activity in colon cancer cells because the IC $\mathrm{C}_{50}$ is less than $100 \mathrm{ppm}$. Moreover, trypan blue exclusion assay showed that $n$-hexane fraction inhibits the proliferation of colon cancer cell and prolongs cell doubling time (fig. 3 ).

Furthermore, this study is the first study that evaluates antiproliferative effects of $n$-hexane fraction of Sarang Semut in Caco-2 cells. Our data showed that $n$-hexane fraction inhibits plating efficiency and area per seed in dose-dependent manner which indicates that Sarang Semut has a highly inhibitory effect of colony formation. The clonogenic assay is an in vitro assay used to test the ability of a single cell to grow into a colony. This method is basically used to evaluate the ability of each cell to perform unlimited cell division [17]. The cells that do not die reproductively and still have the capacity to split and can proliferate indefinitely will form colonies [27]. An ongoing study is conducted to isolate active compounds from this $n$-hexane fraction to get novel potent anticancer compound from sarang semut.

\section{CONCLUSION}

In summary, $n$-hexane fraction of Sarang Semut demonstrates a high potential antitumor activity in colon cancer cell lines, hence further extent of study is necessary to be elucidated more about $n$-hexane fraction of Sarang Semut anti-tumor activity.

\section{ACKNOWLEDGMENT}

This study was part of OCEAN Project supported by Universitas Padjadjaran Fundamental Research Grants for MHB (855/UN6.3.1/ PL/2017). We thank Harold Atmaja for the technical assistance.

\section{AUTHOR CONTRIBUTIONS}

Conceived and designed the experiments: MHB, FH.

Performed the experiments: SH, YARR, TR, NQ.

Analyzed the data: MHB, FH.

Contributed reagents/materials/analysis tools: DK, MHS.

Wrote the paper: MHB, FH, SH, YARR, RGD, DK, MHS

\section{CONFLICT OF INTERESTS}

All authors declare has no conflict of interest 


\section{REFERENCES}

1. Bray F, Ferlay J, Laversanne M, Brewster DH, Gombe Mbalawa $\mathrm{C}$, Kohler B, et al. Cancer incidence in five continents: inclusion criteria, highlights from Vol. X and the global status of cancer registration. Int J Cancer 2015;137:2060-71.

2. Ferlay JSI, Ervik M, Dikshit R, Eser S, Mathers C, Rebelo M, et al. Cancer incidence and mortality worldwide: IARC Cancer Base No. 11:GLOBOCAN 2012 v1.0; 2012. Available from: http://globocan.iarc.fr. [Last accessed on 28 Apr 2017]

3. Andre T, Tournigand C, Achille E, Tubiana Mathieu N, Lledo G, Raoul Y, et al. [Adjuvant treatment of colon cancer MOSAIC study's main results]. Bull Cancer 2006;93 Suppl 1:S5-9.

4. Papamichael D, Audisio RA, Glimelius B, de Gramont A, GlynneJones R, Haller D, et al. Treatment of colorectal cancer in older patients: international society of geriatric oncology (SIOG) consensus recommendations. Ann Oncol 2015;26:463-76.

5. Hammond WA, Swaika A, Mody K. Pharmacologic resistance in colorectal cancer: a review. Ther Adv Med Oncol 2016;8:57-84.

6. Hertiani T, Sasmito E, Sumardi, Ulfah M. Preliminary study on the immunomodulatory effect of sarang-semut tubers Myrmecodia tuberosa and Myrmecodia pendens. Online J Biol Sci 2010;10:136-41.

7. Sudiono J, Oka CT, Trisfilha P. The scientific base of Myrmecodia pendans as herbal remedies. Br J Med Med Res 2015;8:230-7.

8. Soeksmanto A, Subroto MA, Wijaya H, Simanjuntak P. Anticancer activity test for extracts of sarang semut plant (Myrmecodya pendens) to HeLa and MCM-B2 cells. Pak J Biol Sci 2010;13:148-51.

9. Achmad H, Supriatno S, Marhamah M, Rasmidar R. Anti-cancer and anti-proliferation activity of ethanol fraction of ant nest plants (Myrmecodya pendans) on human tongue cancer cell SPC1. IOSR J Dental Med Sci 2014;13:1-5.

10. Yuletnawati SE, Meiyanto E, Agustina D. High antitumor activity of ethanolic extracts of papua's ant nest plant (Myrmecodia tuberosa) on an oral carcinoma (KB) cell line. Int J Sci Res 2016;5:1619-23.

11. Suryawati, Suardi HN, Frengki. editors. The potential antioxidant activity of ethanolic extract of aceh ant-plant (Mymercodia sp) on the free radical DPPH (1, 1-Diphenyl-2pikrylhidrazil). Proceedings of The Annual International Conference, Syiah Kuala University-Life Sciences and Engineering Chapter; 2013.

12. Chahar MK, Sharma N, Dobhal MP, Joshi YC. Flavonoids: a versatile source of anticancer drugs. Pharmacogn Rev 2011;5:1-12.

13. Assi M, Usta J, Mounimne Y, Aboul Ela M, El Lakany A. Phytochemical study and the antiproliferative activity of Inula vulgaris species grown in Lebanon. Int J Pharm Pharm Sci 2017;9:75-83.
14. Rezano A, Kuwahara K, Yamamoto-Ibusuki M, Kitabatake M, Moolthiya P, Phimsen S, et al. Breast cancers with a high DSS1 expression that potentially maintains BRCA2 stability have poor prognosis in the relapse-free survival. BMC Cancer 2013;13:562.

15. Vallet S, Bashari MH, Fan FJ, Malvestiti S, Schneeweiss A, Wuchter $\mathrm{P}$, et al. Pre-osteoblasts stimulate migration of breast cancer cells via the HGF/MET pathway. PLoS One 2016;11:e0150507.

16. Strober W. Trypan blue exclusion test of cell viability. Curr Protoc Immunol 2015;111:A3, B1-3.

17. Franken NA, Rodermond HM, Stap J, Haveman J, Van Bree C. Clonogenic assay of cells in vitro. Nat Protoc 2006;1:2315-9.

18. Guzman C, Bagga M, Kaur A, Westermarck J, Abankwa D. Colony area: an ImageJ plugin to automatically quantify colony formation in clonogenic assays. PLoS One 2014;9:e92444.

19. Brink M, de Goeij AF, Weijenberg MP, Roemen GM, Lentjes MH, Pachen $\mathrm{MM}$, et al. K-ras oncogene mutations in sporadic colorectal cancer in the netherlands cohort study. Carcinogenesis 2003;24:703-10.

20. Shirasawa S, Furuse M, Yokoyama N, Sasazuki T. Altered growth of human colon cancer cell lines disrupted at activated Ki-ras. Science 1993;260:85-8.

21. Phipps AI, Buchanan DD, Makar KW, Win AK, Baron JA, Lindor $\mathrm{NM}$, et al. KRAS-mutation status in relation to colorectal cancer survival: the joint impact of correlated tumour markers. Br J Cancer 2013;108:1757-64.

22. Engida AM, Ju YH. Recovery of antioxidants from Myrmecodia pendans and identification of its major constituent. J Anal Bioanal Tech 2013;2:3.

23. Dirgantara S, Dewi K, Raya J, Simanjuntak T. Studi botani dan fitokimia tiga spesies tanaman sarang semut asal Kabupaten Merauke, Papua. J Pharm Sci Pharm Pract 2015;2:20-3.

24. Engida AM, Kasim NS, Tsigie YA, Ismadji S, Huynh LH, Ju YH. Extraction, identification and quantitative HPLC analysis of flavonoids from sarang semut (Myrmecodia pendan). Ind Crops Prod 2013;41:392-6.

25. Supriatno M. Antitumor activity of papua's Myrmecodia pendans in human oral tongue squamous cell carcinoma cell line through induction of cyclin-dependent kinase inhibitor p27Kip1 and suppression of cyclin E. J Cancer Res Ther 2014;2:48-53.

26. Hasanuddin, Krisnandi S, Supriadi G, Kurnia D, Adhita D. Potential of terpenoid bioactive compound isolated from papua ant nest as an alternative ovarian cancer treatment. Open J Obstetrics Gynecol 2015;5:406-11.

27. Munshi A, Hobbs M, Meyn RE. Clonogenic cell survival assay. Methods Mol Med 2005;110:21-8. 